\title{
Synthesis and Properties Exchange Forms of Granulated Binder-free Zeolite X
}

\author{
I. N. Pavlova ${ }^{1}$, O. S. Travkina ${ }^{1, *}$, B. I. Kutepov ${ }^{1}$, K. R. Ahmed ${ }^{2}$, A. F. Akhme tov ${ }^{2}$ \\ ${ }^{1}$ Institute of Petrochemistry and Catalysis RAS, Ufa, 450075, Russia \\ ${ }^{2}$ Ufa State Petroleum Technological University, Ufa, 450062, Russia
}

\begin{abstract}
Samples of crystalline aluminosilicate, the granules of which are crystalline aggregates of zeolite $\mathrm{X}$ with different degrees of exchange of cations $\mathrm{Na}^{+}$for cations $\mathrm{Ca}^{2+}, \mathrm{Mg}^{2+}, \mathrm{K}^{+}$or $\mathrm{H}^{+}$were synthesized. Based on obtained samples, the adsorption of $\mathrm{H}_{2} \mathrm{O}, \mathrm{CO}_{2}, \mathrm{C}_{6} \mathrm{H}_{6}$ and $\mathrm{n}^{-} \mathrm{C}_{7} \mathrm{H}_{16}$ in static and dynamic modes is studied. The dependencies of the amount of adsorbed substance on the type and content of exchangeable cations in zeolite $\mathrm{X}$ were found.
\end{abstract}

Keywo rds Synthesis, Granules, Zeolite Type A, Adsorption

\section{Introduction}

Granulated zeolites $\mathrm{X}$ in different cationic forms are used in large-tonnage process of adsorption drying and removal of sulfur compounds and $\mathrm{CO}_{2}$, in gas and liquid environments of various composition. Besides, the cationic forms of zeolite $\mathrm{X}$ can be used for adsorption separation of mixtures of hydrocarbons. Adsorption cubic capacity and stability when used in cycles of adsorption-desorption of zeolite adsorbents are determined, first of all, by the phase purity and level of crystallin ity of zeolite, contained in them, nature and content of exchangeable cations in the zeolite cavities, as well as the parameters of their porous structure.

In[1-4] described methods for producing binder-free zeolite $\mathrm{NaX}(\mathrm{NaX}-\mathrm{BF})$, granules of which are crystalline aggregates. Such zeolite granules have higher values of the adsorption characteristics and mechanical strength than the granules with a binder.

The presence of cations in the cavities of the porous structure of zeo lites causes the following features of zeolites as adsorbents[5]:

- the influence of the nature and content of exchangeable cations on the size of the input windows in the cavities;

-during exchange of cations $\mathrm{Na}+$ for other cations change of the latter in the cavities is possible, that leads to changes of limiting volume for filling;

-the specific interaction of polar molecules with exchangeable cations at low degrees of filling of the adsorption volume.

Zeolites $\mathrm{X}$ are usually synthesized in the $\mathrm{Na}$-form.

* Corresponding author:

simchanka@mail.ru (O. S.Travkina)

Published online at http://journal.sapub.org/ijme

Copyright (C) 2012 Scientific \& Academic Publishing. All Rights Reserved
Information in literature about obtaining other cationic forms are given only for highly dispersed and granulated zeolite $\mathrm{X}$ with a binder [6,7]. There is no such information for binder-free zeolite (BF-zeolite). We can assume that the basic laws of the cationic exchange for binder-free zeolite are the same. At the same time, granules of binder-free zeolite are crystalline aggregates, so they may have specific features of behavior usual for exchange process. There is also no information about influence of type and content of exchangeable cations in the BF-zeolite $\mathrm{X}$ on its ability to adsorb substances whose molecules differ in size and structure. According to above-mentioned, present research covers the synthesis of $\mathrm{H}^{+}, \mathrm{K}^{+}, \mathrm{Ca}^{2+}$ or $\mathrm{Mg}^{2+}$ forms of BF-zeolite $\mathrm{X}$ and the adsorption of molecules of $\mathrm{H}_{2} \mathrm{O}, \mathrm{CO}_{2}$, $\mathrm{C}_{6} \mathrm{H}_{6}$ и $\mathrm{H}-\mathrm{C}_{7} \mathrm{H}_{16}$ by them in static and dynamic modes.

\section{Experimental Part}

$\mathrm{H}^{+}, \mathrm{K}^{+}, \mathrm{Ca}^{2+}$ or $\mathrm{Mg}^{2+}$ - forms of BF-zeolite $\mathrm{X}$ with a diameter of $1.6 \mathrm{~mm}$ (HNaX-BF KNaX-BF, CaNaX-BF and $\mathrm{MgNaX}-\mathrm{BF}$ ) were synthesized from its $\mathrm{Na}$-form using ion exchange in solutions of the respective chlorides. Ion exchange experiments were carried out at $700^{\circ} \mathrm{C}$, with initial concentration of salt in a solution of $70 \mathrm{~g} / 1$ ( the ratio of the excess of second exchangeable cation to sodium), at a solution volume-to-zeolite mass ratio of 4 to 1 in an is othermal reactor of periodical operation during 2 hours with stirring. The degree of exchange of $\mathrm{Na}^{+}(\alpha \mathrm{Na})$ for other cations regulated by the amount of exchanges (from 1 to 4 ) without intermed iate heat treatment. $\mathrm{HNa}$-form of $\mathrm{BF}$-zeolite $\mathrm{X}(\mathrm{HNaX}-\mathrm{BF})$ was obtained from $\mathrm{BF}-\mathrm{NH}_{4} \mathrm{NaX}$ using heat treatment after the last exchange at $450{ }^{\circ} \mathrm{C}$ during 4 hours in the open air. As a comparison with these results, we also obtained exchangeable forms of highly dispersed zeolite $\mathrm{NaX}$ with a partic le size of $1.0-8.0$ microns. 
The chemical compositions of liquid and solid phases were analyzed using gravimetric method, as well as methods of comp le xo metric titration and flame photometry[8].

The phase composition of the zeolites were determined using X-ray analysis on an automatic diffractometer PHILIPS PW 1800. To determine used the method of Debye - Scherrer (powder method). Analysis conditions: theta/2 theta -scanning; rotation of holder-one turn $\mathrm{sec}^{-1}$, anode material-copper, range $-5-550 / 2$ theta; step - $0.05^{\circ}$; exposure step - 2 seconds, anode voltage and current - $40 \mathrm{~kW}$ and 30 $\mathrm{mA}$, respectively. Radiographs were identified by the known diffraction data[9].

To determine the parameters of porous structure ( pore's size and distribution radius, specific surface area) used the low-temperature nitrogen adsorption measured by static vacuum volumetric automated installation "Sorptomatic1900" ("Fisons")[10-12], and mercury porosimetry using «Porosimeter-2000"[13].

To determine the equilibrium adsorption cubic capacities $\left(\mathrm{cm}^{3} / \mathrm{g}\right)$ for $\mathrm{H}_{2} \mathrm{O}-\mathrm{A}\left(\mathrm{H}_{2} \mathrm{O}\right), \mathrm{C}_{6} \mathrm{H}_{6}-\mathrm{A}\left(\mathrm{C}_{6} \mathrm{H}_{6}\right)$ and $\mathrm{n}-\mathrm{C}_{7} \mathrm{H}_{16}-$ $\mathrm{A}\left(\mathrm{n}-\mathrm{C}_{7} \mathrm{H}_{16}\right)$ of obtained adsorbents used the excicatory method, which is widespread in industry.[14]

Measurements were made at $20^{\circ} \mathrm{C}$. To determine $\mathrm{A}\left(\mathrm{H}_{2} \mathrm{O}\right)$ in excicator added an aqueous solution of sulfuric acid, which provides $\mathrm{P} / \mathrm{Ps}=0,7$, and pure benzine and heptane to determine $\mathrm{A}\left(\mathrm{C}_{6} \mathrm{H}_{6}\right)$ and $\mathrm{A}\left(\mathrm{n}-\mathrm{C}_{7} \mathrm{H}_{16}\right)$ respectively. A $\left(\mathrm{CO}_{2}\right)$ was measured at concentrations of $\mathrm{CO}_{2}$ in a binary mixture with helium, equal to 70.0 and $0.03 \%$ vol. During the experiment samples were removed from the excicator and weighed. The experiment was stopped when a constant sample weight had been obtained.

To assess the impact of the replacement of the cations $\mathrm{Na}^{+}$ by other cations on the adsorption cubic capacity of granules of $\mathrm{BF}$-zeolite $\mathrm{X}$ in the dynamic mode was measured its adsorption cubic capacity for $\mathrm{H}_{2} \mathrm{O}-\mathrm{D}\left(\mathrm{H}_{2} \mathrm{O}\right), \mathrm{CO}_{2}-\mathrm{D}\left(\mathrm{CO}_{2}\right)$, $\mathrm{C}_{6} \mathrm{H}_{6}-\mathrm{D}\left(\mathrm{C}_{6} \mathrm{H}_{6}\right)$ and $\mathrm{n}-\mathrm{C}_{7} \mathrm{H}_{16}-\mathrm{D}\left(\mathrm{n}-\mathrm{C}_{7} \mathrm{H}_{16}\right)$ from mixtures with air in a flow adsorber at atmospheric pressure, temperature $20-25^{\circ} \mathrm{C}$ and the amount of the loaded adsorbent up to $150 \mathrm{~cm}^{3}$. The rate of steam or air-gas flow was $4,0 \pm$ $0,25 \mathrm{dm}^{3} /$ min for a mixture with $\mathrm{C}_{6} \mathrm{H}_{6}$ and $n-\mathrm{C}_{7} \mathrm{H}_{16}$ at vapor concentrations of $12-15 \mathrm{mg} / \mathrm{dm}^{3}$, and $1,0 \pm 0,25 \mathrm{dm}^{3} / \mathrm{min}$ for a mixture of $\mathrm{H}_{2} \mathrm{O}$ and $\mathrm{CO}_{2}$ at a concentration of $13-15 \mathrm{mg} / \mathrm{d} \mathrm{m}^{3}$ and $200 \mathrm{mg} / \mathrm{d} \mathrm{m}^{3}$, respectively. The adsorption experiment was stopped after reaching "the skip" concentration corresponding to $-70^{\circ} \mathrm{C}$ for $\mathrm{H}_{2} \mathrm{O}$ and $-60^{\circ} \mathrm{C}$ for $\mathrm{C}_{6} \mathrm{H}_{6}$ and $\mathrm{n}-\mathrm{C}_{7} \mathrm{H}_{16}$. In the case of $\mathrm{CO}_{2}$ experiment was stopped when it comes out of the adsorber.

\section{Results and Discussion}

Figure 1 shows the results of studying the influence of the nature of exchangeable cation and the number of treatments with $\alpha \mathrm{Na}$ during exchange for cations $\mathrm{H}^{+}, \mathrm{K}^{+}, \mathrm{Ca}^{2+}$ or $\mathrm{Mg}^{2+}$ in the zeolite $\mathrm{NaX}-\mathrm{BF}$. To co mpare results here stated data of similar exchanges in the samples of highly dispersed zeolite $\mathrm{NaX}$.
Presented results show that in order to achieve maximum $\alpha \mathrm{Na}$ in zeolite $\mathrm{NaX}-\mathrm{BF}$ three exchange treatments are required. Any further increasing in their number has no significant impact.
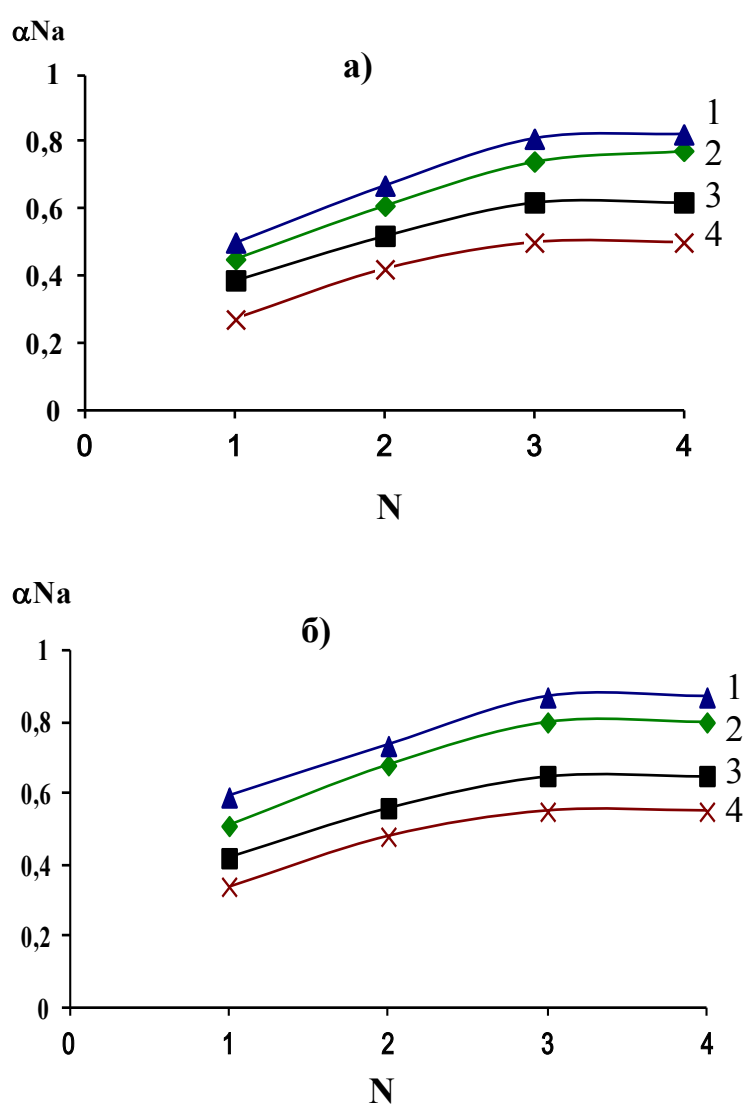

where $\mathrm{N}$ is for number of exchangeable treatments; a) $(\alpha \mathrm{Na})$ - Degree of exchange of cat ions $\mathrm{Na}^{+}$in zeolite $\mathrm{NaX}-\mathrm{BF}$ for $\mathrm{K}^{+}(1)$; $\mathrm{Ca}^{2+}(2) ; \mathrm{H}^{+}(3) ; \mathrm{Mg}^{+2}(4)$;

b) $(\alpha \mathrm{Na})$ - Degree of exchange of cations $\mathrm{Na}^{+}$in zeolite $\mathrm{NaX}$ for $\mathrm{K}^{+}(1)$; $\mathrm{Ca}^{2+}(2) ; \mathrm{H}^{+}(3) ; \mathrm{Mg}^{+2}(4)$

Figure 1. Figure 1. Influence of the nature of exchangeable cation and number of treatments on the degree of exchange in the granular (a) and highly dispersed (b) zeolites of type X

Comparison of values of $\alpha \mathrm{Na}$ in granular and highly dispersed samples with the same number of treatments, showed that the granular exchange proceeds more slowly, apparently due to diffusion limitations.

The maximum values of $\alpha \mathrm{Na}$ during exchange for cations $\mathrm{H}^{+}, \mathrm{K}^{+}, \mathrm{Ca}^{2+}$ or $\mathrm{Mg}^{2+}$ are $0.64,0.82 ; 0.79$ and 0.52 , respectively. The discrepancy between the values is determined by difference of their own size and energy of hydration of above-mentioned ions [6, 7]. For highly dispersed zeolite $\mathrm{NaX} \alpha \mathrm{Na}$ is $0.66,0.87,0.83,0.56$, respectively (Fig. 1).

$\mathrm{X}$-ray analysis shows that degree of crystallinity of the highly dispersed zeolite $\mathrm{X}$ before exchange is close to $100.0 \%$, and for the NaX-BF it makes $90,0-94,0 \%$. After an exchange of $\mathrm{Na}^{+}$cations for the above-mentioned cations, these values are almost unchanged. 
The values of the mechanical crush strength of granules (butt-end crush) during of the exchange does not change and make $2.0-2.2 \mathrm{~kg} / \mathrm{mm}^{2}$.

Taking into account the fact that the characteristics of granulated zeolite's pore structure have a significant impact on the amount of material adsorbed in the dynamic mode, these characteristics of samples of zeolite NaX-BF were measured before and after the exchange treatments. The results are shown in Table 1.

Results of determination of $\mathrm{A}\left(\mathrm{H}_{2} \mathrm{O}\right), \mathrm{A}\left(\mathrm{H}-\mathrm{C}_{7} \mathrm{H}_{16}\right)$ and $\mathrm{A}\left(\mathrm{C}_{6} \mathrm{H}_{6}\right)$ for zeolite $\mathrm{X}-\mathrm{BF}$ in the above-mentioned cationic forms as well as similar characteristics of the samples of powdered zeolite $\mathrm{X}$ for comparison are shown in Tables $2-4$.

Table 1. Parameters of the porous structure of cationic forms of zeolite X-BF

\begin{tabular}{|c|c|c|c|c|}
\hline \multirow{2}{*}{$\begin{array}{c}\text { Cationic form of } \\
\text { zeolite }\end{array}$} & $\begin{array}{c}\mathrm{V}_{\text {por, }} \\
\mathrm{cm}^{3} / \mathrm{g}\end{array}$ & $\begin{array}{c}\mathrm{R}_{\text {averge, }}^{\mathrm{o}} \\
\AA\end{array}$ & $\begin{array}{c}\mathrm{S}_{\text {specific, }} \\
\mathrm{m}^{2} / \mathrm{g}\end{array}$ & \multirow{2}{*}{$\begin{array}{c}\mathrm{S}_{\text {specific }}, \mathrm{m}^{2} / \mathrm{g} \\
\text { nitrogen }\end{array}$} \\
\cline { 2 - 4 } & \multicolumn{3}{|c|}{ mercury } & 364 \\
\hline NaX-BF & 0,24 & 963 & 3,9 & 370 \\
\hline $0,64 \mathrm{HNaX}-\mathrm{BF}$ & 0,35 & 1250 & 7,9 & 316 \\
\hline $0,82 \mathrm{KNaX}-\mathrm{BF}$ & 0,30 & 1230 & 7,5 & 403 \\
\hline $0,79 \mathrm{CaNaX}-\mathrm{BF}$ & 0,29 & 1258 & 5,8 & 396 \\
\hline $0,52 \mathrm{MgNaX}-\mathrm{BF}$ & 0,28 & 1222 & 5,4 & 364 \\
\hline
\end{tabular}

Data from Table 1 shows that the parameters of the porous structure of granules after the exchange remain unchanged.

Table 2. $\mathrm{A}\left(\mathrm{H}_{2} \mathrm{O}\right)$ of zeolites $\mathrm{X}$ in different cationic forms

\begin{tabular}{|c|c|c|c|}
\hline $\begin{array}{c}\text { Cationic form of } \\
\text { zeolite }\end{array}$ & $\begin{array}{c}\mathrm{A}\left(\mathrm{H}_{2} \mathrm{O}\right) \mathrm{c} \\
\mathrm{m}^{3} / \mathrm{g}\end{array}$ & $\begin{array}{c}\text { Cationic form } \\
\text { of zeolite }\end{array}$ & $\begin{array}{c}\mathrm{A}\left(\mathrm{H}_{2} \mathrm{O}\right) \\
\mathrm{cm}^{3} / \mathrm{g}\end{array}$ \\
\hline $\mathrm{NaX}-\mathrm{BF}$ & 0,27 & $\mathrm{NaX}$ & 0,30 \\
\hline $0,64 \mathrm{HNaX}-\mathrm{BF}$ & 0,22 & $0,66 \mathrm{HNaX}$ & 0,25 \\
\hline $0,82 \mathrm{KNaX}-\mathrm{BF}$ & 0,26 & $0,87 \mathrm{KNaX}$ & 0,29 \\
\hline $0,79 \mathrm{CaNaX}-\mathrm{BF}$ & 0,27 & $0,83 \mathrm{CaNaX}$ & 0,29 \\
\hline $0,52 \mathrm{MgNaX}-\mathrm{BF}$ & 0,28 & $0,56 \mathrm{MgNaX}$ & 0,32 \\
\hline
\end{tabular}

Table 3. A(n- $\left.\mathrm{C}_{7} \mathrm{H}_{16}\right)$ of zeolites $\mathrm{X}$ in different cationic forms

\begin{tabular}{|c|c|c|c|}
\hline $\begin{array}{c}\text { Cationic form of } \\
\text { zeolite }\end{array}$ & $\begin{array}{c}\mathrm{A}\left(\mathrm{n}-\mathrm{C}_{7} \mathrm{H}_{16}\right) \\
\mathrm{cm}^{3} / \mathrm{g}\end{array}$ & $\begin{array}{c}\text { Cationic form of } \\
\text { zeolite }\end{array}$ & $\begin{array}{c}\mathrm{A}\left(\mathrm{n}-\mathrm{C}_{7} \mathrm{H}_{16}\right) \\
\mathrm{cm}^{3} / \mathrm{g}\end{array}$ \\
\hline $\mathrm{NaX}-\mathrm{BF}$ & 0,28 & $\mathrm{NaX}$ & 0,30 \\
\hline $0,64 \mathrm{HNaX}-\mathrm{BF}$ & 0,23 & $0,66 \mathrm{HNaX}$ & 0,27 \\
\hline $0,82 \mathrm{KNaX}-\mathrm{BF}$ & 0,27 & $0,87 \mathrm{KNaX}$ & 0,29 \\
\hline $0,79 \mathrm{CaNaX}-\mathrm{BF}$ & 0,29 & $0,83 \mathrm{CaNaX}$ & 0,30 \\
\hline $0,52 \mathrm{MgNaX}-\mathrm{BF}$ & 0,28 & $0,56 \mathrm{MgNaX}$ & 0,31 \\
\hline
\end{tabular}

Table 4. $\mathrm{A}\left(\mathrm{C}_{6} \mathrm{H}_{6}\right)$ of zeolites $\mathrm{X}$ in different cationic forms

\begin{tabular}{|c|c|c|c|}
\hline $\begin{array}{c}\text { Cationic form of } \\
\text { zeolite }\end{array}$ & $\begin{array}{c}\mathrm{A}\left(\mathrm{C}_{6} \mathrm{H}_{6}\right) \\
\mathrm{cm}^{3} / \mathrm{g}\end{array}$ & $\begin{array}{c}\text { Cationic form } \\
\text { of zeolite }\end{array}$ & $\begin{array}{c}\mathrm{A}\left(\mathrm{C}_{6} \mathrm{H}_{6}\right) \\
\mathrm{cm}^{3} / \mathrm{g}\end{array}$ \\
\hline $\mathrm{NaX}-\mathrm{BF}$ & 0,26 & $\mathrm{NaX}$ & 0,30 \\
\hline $0,64 \mathrm{HNaX}-\mathrm{BF}$ & 0,22 & $0,66 \mathrm{HNaX}$ & 0,25 \\
\hline $0,82 \mathrm{KNaX}-\mathrm{BF}$ & 0,26 & $0,87 \mathrm{KNaX}$ & 0.28 \\
\hline $0,79 \mathrm{CaNaX}-\mathrm{BF}$ & 0,26 & $0,83 \mathrm{CaNaX}$ & 0,29 \\
\hline $0,52 \mathrm{MgNaX}-\mathrm{BF}$ & 0,27 & $0,55 \mathrm{MgNaX}$ & 0,30 \\
\hline
\end{tabular}

It is obvious that equilibrium adsorptive cubic capacities of granular samples is $10,0-15,0 \%$ less than of powdery samples. The main reason of smaller adsorptive cubic capacity of granules is that they correspond to an aggregate of nanodimensional crystals and part of its intracrystalline space can be inaccessible for molecules of adsorbate.

The results, represented in tables 2-4, show that during transition from $\mathrm{NaX}-\mathrm{BF}$ to $\mathrm{KNaX}-\mathrm{BF}, \mathrm{CaNaX}-\mathrm{BF}$ or $\mathrm{MgNaX}-\mathrm{BF}$ with maximum degrees of exchange, there were no considerable changes in the values of $\mathrm{A}\left(\mathrm{H}_{2} \mathrm{O}\right), \mathrm{A}\left(\mathrm{C}_{6} \mathrm{H}_{6}\right)$ and $\mathrm{A}\left(\mathrm{H}-\mathrm{C}_{7} \mathrm{H}_{16}\right)$.

Table 5 represents the results of the research of $\mathrm{CO}_{2}$ adsorption on the zeolite $\mathrm{X}$ in different cationic forms. It is clear that when the $\mathrm{CO}_{2}$ concentration is equal to $70,0 \%$, the values of maximum $\mathrm{CO}_{2}$ adsorptive cubic capacities for all cationic forms of zeo lites $\mathrm{X}$ are also similar (table 5).

Table 5. A $\left(\mathrm{CO}_{2}\right)$ of zeolites $\mathrm{X}$ in different cationic forms

\begin{tabular}{|c|c|c|c|c|c|}
\hline $\begin{array}{c}\text { Cationic } \\
\text { form of } \\
\text { zeolite }\end{array}$ & $\begin{array}{c}\mathrm{A}\left(\mathrm{CO}_{2}\right)^{1} \\
\mathrm{~cm}^{3} / \mathrm{g}\end{array}$ & $\begin{array}{c}\mathrm{A}\left(\mathrm{CO}_{2}\right) \\
{ }_{\mathrm{cm}} / \mathrm{g}\end{array}$ & $\begin{array}{c}\text { Cationic } \\
\text { form of } \\
\text { zeolite }\end{array}$ & $\begin{array}{c}\mathrm{A}\left(\mathrm{CO}_{2}\right) \\
\mathrm{cm}^{3} / \mathrm{g}\end{array}$ & $\begin{array}{c}\mathrm{A}\left(\mathrm{CO}_{2}\right) \\
\mathrm{cm}^{3} / \mathrm{g}\end{array}$ \\
\hline $\mathrm{NaX-BF}$ & 0,26 & 0,22 & $\mathrm{NaX}$ & 0,30 & 0,28 \\
\hline $\begin{array}{c}0,64 \mathrm{HNa} \\
\mathrm{X}-\mathrm{BF}\end{array}$ & 0,24 & 0,10 & $\begin{array}{c}0,66 \mathrm{H} \\
\mathrm{NaX}\end{array}$ & 0,27 & 0,15 \\
\hline $\begin{array}{c}0,82 \mathrm{KNa} \\
\text { X-BF }\end{array}$ & 0,25 & 0,13 & $\begin{array}{c}0,87 \mathrm{~K} \\
\mathrm{NaX}\end{array}$ & 0,28 & 0,16 \\
\hline $\begin{array}{c}0,79 \mathrm{CaN} \\
\text { aX-BF }\end{array}$ & 0,26 & 0,12 & $\begin{array}{c}0,83 \mathrm{Ca} \\
\mathrm{NaX}\end{array}$ & 0,29 & 0,19 \\
\hline $\begin{array}{c}0,52 \mathrm{Mg} \\
\mathrm{NaX}-\mathrm{BF}\end{array}$ & 0,25 & 0,11 & $\begin{array}{c}0,56 \mathrm{Mg} \\
\mathrm{NaX}\end{array}$ & 0,30 & 0,17 \\
\hline
\end{tabular}

${ }^{1}-\mathrm{CO}_{2}$, concentration $-70,0 \%$., ${ }^{2}-\mathrm{CO}_{2}$ concentration, $-0,03 \%$.

The obtained results are explained by the fact that in the researched conditions volumetric filling of microcellular intracrystalline space of zeolite $\mathrm{X}$-BF takes place. In this case $\mathrm{A}\left(\mathrm{H}_{2} \mathrm{O}\right), \mathrm{A}\left(\mathrm{C}_{6} \mathrm{H}_{6}\right), \mathrm{A}\left(\mathrm{n}-\mathrm{C}_{7} \mathrm{H}_{16}\right)$ and $\mathrm{A}\left(\mathrm{CO}_{2}\right)\left(\mathrm{CO}_{2}\right.$ concentration $=70,0 \%$.) are mainly defined by its volume and by sizes of entrance windows in cavity. In transition from one cationic form, studied in this work, to another the indicated characteristics in zeolite $\mathrm{X}$ practically do not change.

The nature and content of the cation in zeolite X-BF become apparent in case of s mall degrees of filling. In the present work such results were obtained for $\mathrm{CO}_{2}$. From the data of table 5 it is clear that $\mathrm{NaX}-\mathrm{BF}$, for which the lower surface acidity is characteristic, adsorb $\mathrm{CO}_{2}$ when its concentration is equal to $0,03 \%$, that is $1,5-2$ times more than other exchange forms of the same zeolites.

Table 6. $\mathrm{A}\left(\mathrm{CO}_{2}\right)$ of zeolites $\mathrm{X}$ in different cationic forms

\begin{tabular}{|c|c|c|c|c|}
\hline $\begin{array}{c}\text { Cationic form of } \\
\text { zeolite }\end{array}$ & $\begin{array}{c}\mathrm{D}\left(\mathrm{H}_{2} \mathrm{O}\right) \\
\mathrm{mg} / \mathrm{cm}^{3}\end{array}$ & $\begin{array}{c}\mathrm{D}\left(\mathrm{n}-\mathrm{C}_{7} \mathrm{H}_{16}\right) \\
\mathrm{mg} / \mathrm{cm}^{3}\end{array}$ & $\begin{array}{c}\mathrm{D}\left(\mathrm{C}_{6} \mathrm{H}_{6}\right) \\
\mathrm{mg} / \mathrm{cm}^{3}\end{array}$ & $\begin{array}{c}\mathrm{D}\left(\mathrm{CO}_{2}\right) \\
\mathrm{mg} / \mathrm{cm}^{3}\end{array}$ \\
\hline NaX-BF & 159 & 90 & 88 & 55 \\
\hline $0,64 \mathrm{HNaX}-\mathrm{BF}$ & 109 & 65 & 62 & 24 \\
\hline $0,82 \mathrm{KNaX}-\mathrm{BF}$ & 139 & 89 & 87 & 54 \\
\hline 0,79CaNaX-BF & 143 & 80 & 88 & 49 \\
\hline 0,52MgNaX-BF & 138 & 82 & 80 & 48 \\
\hline
\end{tabular}


Table 6 contains the results of the research concerning the influence of type and content of exchange cations in zeolite $\mathrm{X}-\mathrm{BF}$ on its adsorptive cubic capacities $\left(\mathrm{mg} / \mathrm{sm}^{3}\right)$ of $\mathrm{H}_{2} \mathrm{O}$ $\mathrm{D}\left(\mathrm{H}_{2} \mathrm{O}\right), \mathrm{n}-\mathrm{C}_{7} \mathrm{H}_{16}-\mathrm{D}\left(\mathrm{n}-\mathrm{C}_{7} \mathrm{H}_{16}\right), \mathrm{C}_{6} \mathrm{H}_{6}-\mathrm{D}\left(\mathrm{C}_{6} \mathrm{H}_{6}\right)$ and $\mathrm{CO}_{2}-$ $\mathrm{D}\left(\mathrm{CO}_{2}\right)$ in running adsorber.

It is obvious that in flow reactor with high speeds of gas stream the differences in values of $\mathrm{D}\left(\mathrm{H}_{2} \mathrm{O}\right), \mathrm{D}\left(\mathrm{C}_{6} \mathrm{H}_{6}\right)$, $\mathrm{D}\left(\mathrm{n}-\mathrm{C}_{7} \mathrm{H}_{16}\right)$ and $\mathrm{D}\left(\mathrm{CO}_{2}\right)$ for all cationic forms of zeolites $\mathrm{X}$ do not exceed experimental error.

Other results were obtained while studying adsorption on decationed form of zeolite $\mathrm{X}-\mathrm{BF}$ with the degree of exchange of cations $\mathrm{Na}^{+}$for $\mathrm{H}^{+}$equal to 0,6 . The data in tables 2-4 show that adsorptive cubic capacities of $\mathrm{HNaX}-\mathrm{BF}$, especially in flow regime, are considerably reduce. The maximu $\mathrm{m}$ decrease typical for $\mathrm{CO}_{2}$ because decating results in the increase of zeolite surface acidity. We can also suppose that removal from the intracrystalline space of cations, that are able to interact with the molecules of adsorbate, reduce the diffusion rate of the latter in the cavity of zeo lite.

\section{Conclusions}

Ion exchange of cations $\mathrm{Na}^{+}$for cations $\mathrm{H}^{+}, \mathrm{K}^{+}, \mathrm{Ca}^{2+}$ or $\mathrm{Mg}^{2+}$ in granular zeolite binder-free $\mathrm{NaX}$ was studied. This study showed that degree of exchange after first processing and final degrees of exchange are 10,0-15,0\% lower than exchange in fine-grained samples because of lower cations' diffusion rate and inaccessibility of the part of intracrystalline space in granules, which correspond to integrated crystalline aggregates. It was found out that in granules the maximum values of the degrees of exchange of $\mathrm{Na}^{+}$for $\mathrm{H}^{+}, \mathrm{K}^{+}, \mathrm{Ca}^{2+}$ or $\mathrm{Mg}^{2+}$ are different: 0,$64 ; 0,82 ; 0,79$; 0,52 according ly. After exchange high degree of crystallinity and parameters of porous structure of granules are invariable.

It was found out that granular zeolite $\mathrm{X}$ without binding material in different cationic forms has maximum adsorptive cubic capacities of $\mathrm{H}_{2} \mathrm{O}, \mathrm{CO}_{2}, \mathrm{C}_{6} \mathrm{H}_{6}$ and $\mathrm{n}_{-} \mathrm{C}_{7} \mathrm{H}_{16}$ that are $10,0-15,0 \%$ lower than maximum adsorptive cubic capacities of fine-grained samples because of inaccessibility of the part of intracrystalline space in granules. The research showed that in zeolite X-BF during the transition from Na-form to K, Ca or Mg-form with maximum degrees of exchange and in condition of $20^{\circ} \mathrm{C}$ and high concentrations of adsorbates there is no significant changes of equilibrium adsorptive cubic capacities of $\mathrm{H}_{2} \mathrm{O}, \mathrm{CO}_{2}, \mathrm{C}_{6} \mathrm{H}_{6}$ and $\mathrm{n}-\mathrm{C}_{7} \mathrm{H}_{16}$. If the $\mathrm{CO}_{2}$ concentration is $0,03 \%$ - because of its minimal acidity 1,5-2 times more $\mathrm{CO}_{2}$ adsorbs on Na-form of the zeolites X than on other exchange forms of the same zeo lites. It was also found out that production of decationed form of zeolite X-BF results in reduction of its adsorption property. For HNa-forms with the degrees of exchange of 0,6 adsorptive cubic capacities of $\mathrm{H}_{2} \mathrm{O}$ and $\mathrm{CO}_{2}$ in flow reactor reduce for 1,5 and 2,0 times accordingly.

\section{REFERENCES}

[1] Pat. RUS № 2203224 Method of obtainment of synthetic granular faujasite of high phase purity. Glukhov V.A., Glukhov A.V.

[2] Pat. RUS № 2283278 Method of obtainment of granular zeolite adsorbent of structure A and X of high phase purity. Rakhimov Kh.Kh., Pavlov M.L., Kutepov B.I., Makhamatkhanov R.A. and others

[3] Pat. RUS № 2322391 Method of obtainment of synthetic granular zeolite of X type. Glukhov V.A., Zelenov L.E., Zelenov A.V.

[4] Kutepov B.I., Pavlov M.L., Pavlova I.N., Travkina O.S., Basimova R.A. «Syntheses of high-performance A and X type binder-free zeolites from kaolin», Petrochemistry, vol.49, no.1, pp.39-442, 2009

[5] Zhdanov S.P., Khvoschev S.S., Samulevich N.N. Synthetic zeolites, 264p., 1981

[6] Breck D. Zeolite molecular sieves, 781p., 1976

[7] Tolmachev A.M. The study of zeolites as selective ion exchangers for division of mixes of substances similar in qualities and isotopes. Modern problems of physical chemistry., vol.10, pp.134-190, 1978

[8] Kreschkov A.P., Yaroslavtsev A.A. Course of analytical chemistry., 471p., 1975

[9] Treacy M.M.J., Higgins J.B. Collection of Simulated XRD Powder Patterns for Zeolites. Amsterdam - London - New York - Oxford - Paris - Shannon - Tokyo, Elsevier, 586 p., 2001

[10] Branawer S. Adsorption of gases and steams., T. I., 781p., 1948

[11] Greg S., Sing K. Adsorption. Specific surface. Porosity., 310p., 1984.

[12] V.B. Fenelonov, L.G. Okkel, N.S. Slydkina, T.M. Malygina Devices and technics of experiment., no.4., pp.133-136, 1997.

[13] Plachenov T.G., Kolosentsev S.D. Porometry., 175p., 1988

[14] Keltsev N.V. Basis of adsorptive technics., 592p., 1984 